\title{
THE ROLE OF THE SPIRIT BAPTISM IN PAULINE ESCHATOLOGY
}

\author{
Jefri Hina Remi Katu
}

\begin{abstract}
This paper presents the eschatological view of the Spirit Baptism in Paul's writing. The Spirit Baptism and eschatology in Paul's perspective are thoughts that function hand in hand with each other and cannot be separated. In Paul, Spirit Baptism is the fulfilment of the Old Testament promise in which God declares to His people that He will be with (stay among) His people through the pouring out of His Spirit. This promise is understood by His people as the eschatological promise of God. This pouring out of the Spirit upon God's people should be understood as the doctrine of Spirit Baptism which has eschatological role in Paul's theology. This paper will emphasize the background of Paul's understanding of the Spirit Baptism as it relates to the soteriological dimension work of the Holy Spirit.
\end{abstract}

Keywords: Spirit Baptism, Eschatology, Paul's Background

\section{$\underline{\text { Introduction }}$}

The term eschatology literally means a study about the last things, in other words, eschatology is about the end of the world. Gordon Fee states that the concept of eschatology in the early Church has a unique understanding of the end of the time. ${ }^{1}$ The unique understanding of eschatology in the early church is understood through the proclamation of Jesus about the present reality of the Kingdom of God in His ministry, although also as the Kingdom of God is a future event. ${ }^{2}$ Therefore, John Panteleimon Manoussakis explains, "Christian eschatology as unfolds as this tension between two eschatological modal points: between the already of the Incarnation and the not yet of the Parousia (cf. John 3:8: 4:23; 5:25; 12:31)."3

The resurrection of Jesus from the death and the promise of the pouring out the Holy Spirit upon the church is an eschatological fulfillment in which the early church

\footnotetext{
${ }^{1}$ Gordon D. Fee, God's Empowering Presence: the Holy Spirit in the Letters of Paul (Peabody, MA: Hendrickson Publishers, 1994), 803.

${ }^{2}$ Ibid.

${ }^{3}$ John Panteleimon Manoussakis, "The Promise of the New and the Tyranny of the Same," Pneumatology and Eschatology: Not Yet in the Now, edited by Neal Deroo and John P. Manoussakis (Barlington, USA: Ashgate Publishing Company, 2009), 73.
} 
recognized that the future had already been set in the present. ${ }^{4}$ George Eldon Ladd emphasizes,

"The redemptive blessings brought to human beings by Jesus' death and resurrection and the giving of the Holy Spirit are eschatological events." ${ }^{5}$

Pneumatology and eschatology in Pauline theology are interrelated and inseparable. Max Turner states that the experience of the indwelling of the Holy Spirit in believers in the present time is foretaste of the eschatological goal of the work of the Holy Spirit that has already been achieved in and by Christ. 6 Therefore, the role of the Holy Spirit Baptism in Paul's theology cannot be separated from the concept of eschatology.

This paper discusses Paul's understanding of eschatology as it relates to his view of Spirit Baptism and how he develops his eschatology in relation to the work of the Holy Spirit in the believers.

\section{Paul's background thoughts}

Paul states that he was a Pharisee and being a Pharisee was a prestigious attainment. He was zealous Pharisee, persecuting the early Christian church, and as a Pharisee, he felt himself to be blameless and righteous. However, now that his is in Christ he saw the sinful nature of his past life. Now he sees his salvation in Christ and shared suffering with Christ as an eschatological expectation (Phil. 3:4b-11). ${ }^{7}$

In Galatians 1:13-14, Paul emphasizes his Jewish background and what he did before he became a follower of Christ. According these passages, Paul states that he received a Pharisaic education, was a zealous guardian of the law and persecuted those whom he felt impugned and violated the law. ${ }^{8}$ N. T. Wright explains that Paul was zealous for God and zealous for first century Jewish traditions. ${ }^{9}$

\footnotetext{
${ }^{4}$ Fee, God's Empowering Presence, 803.

${ }^{5}$ George Eldon Ladd, A Theology of the New Testament, revised edition (Grand Rapids, MI: William B. Eerdmans Publishing Company, 1993), 596.

${ }^{6}$ Max Turner, Spiritual Gifts in the New Testament Church and Today, revised edition (Peabody, MA: Hendrickson Publishers, 1998), 124.

${ }^{7}$ Allan F. Segal, "Paul's Jewish Presuppositions," The Cambridge Companion to St. Paul, edited by James Dunn (Cambridge, UK: Cambridge University Press, 2004), 159.

${ }^{8}$ Ibid., 160.

${ }^{9}$ N. T. Wright, What Saint Paul Really Said: Was Paul of Tarsus the Real Founder of Christianity? (Grand Rapids, MI: William B. Eerdmans Publishing Company, 1997), 27.
} 
Paul's experience on the road to Damascus changed his perspective and he came to believe that Jesus is the Messiah who was resurrected from the death by the Holy Spirit (cf. Rom. 1:4). The age to come had already inaugurated in the present time. ${ }^{10}$ The death and resurrection of Jesus is the great eschatological event that reveals God's covenant faithfulness. ${ }^{11}$ "Reveal" means apocalypse and according to the apocalypse that Paul experience he was already living in the end of time. In other words, Wright emphasizes that the experience of Paul in the road to Damascus equipped him with an entirely new perspective that the age to come had been inaugurated..$^{12}$

Turner states that the early disciples had a fundamental understanding of the Holy Spirit from their Jewish understanding the Old Testament that they heard in the weekly synagogue readings. ${ }^{13}$ As a Jew who was zealous for the law as the Old Testament, Paul probably had the same understanding about the Holy Spirit and His role to the people of God. Turner adds, "The various groups within the Judaism thus came to emphasize different aspects of the Spirit's work and to play down others."14

There were a wide variety of opinions about the life to come in the Judaism of Paul's time. F. F. Bruce says that Paul inherited the belief in bodily resurrection from the widespread belief among the Pharisees. ${ }^{15}$ The relationship between the pneumatology and the eschatology in Pauline theology leads to the understanding that it is the indwelling of the Holy Spirit that will give life to the mortal bodies of the believers (Rom. 8:11). Therefore, the Holy Spirit is the initial "down payment" that guarantees for the eternal life in the age to come. ${ }^{16}$

Jewish Hope

Apocalyptic writing is a form of Jewish literature. ${ }^{17}$ In several places Paul makes refers to the apocalyptic concepts of heaven and the two ages. He discusses the concept

\footnotetext{
${ }^{10}$ Ibid., 37.

${ }^{11}$ Ibid., 37.

12 Ibid., 37.

13 Turner, Spiritual Gifts in the New Testament Church and Today, 1.

${ }^{14}$ Ibid.
}

${ }^{15}$ F, F. Bruce, Paul: Apostle of the Heart Set Free (Grand Rapids, MI: William B. Eerdman Publisher, 1997), electronic edition, 312.

${ }^{16}$ Ladd, A Theology of the New Testament, 610.

${ }^{17}$ George Eldon Ladd, The Present of the Future: The Eschatology of Biblical Realism, revised edition (Grand Rapids, MI: William Eerdmans Publishing Company, 2002), 77. 'The word 'apocalyptic' is derived from the New Testament Apocalypse I: I CHECK THE WORDING OF THIS QUOTE HERE and is applied by modern scholars to a particular type of Jewish writing produced between 200 B.C. and A.D. 100. Most 
of a heavenly Jerusalem (Gal. 4:26), paradise and third heaven (2 Cor. 12), the age to come present in heaven and entered into at death (2 Cor. 5; Phil. 1: 23), the hope laid up in heaven (Col. 1: 5), the 'hidden-revealed' motif, the theme of glory (Col. 3: 1-4), the mystery of God's cosmic plan (Eph. 1: 10), the session in heaven (Eph. 2: 6), the heavenly temple (Eph. 2: $20 \mathrm{ff}$ ) and the cosmic battle (Eph. 6: $10 \mathrm{ff}) .{ }^{18}$

Resurrection language is a part of Jewish apocalyptic thought that belongs to the new age and the transformation and re-creation of everything. Therefore, apocalyptic in Jewish understanding refers to the victory of God. ${ }^{19}$ G. W. E. Nickelsburg states that in Jewish inter-testamental theology belief in resurrection, immortality, and eternal life are found within the framework of three forms already established in or and have specific functions within these domains, namely the story of the righteousness man, the judgment scene, and the two-way theology. ${ }^{20}$

Martinus C. de Boer says that most of the Jewish texts from ca 200 BCE to ca. 100 CE exhibit apocalyptic eschatology.21 This Jewish apocalyptic literature, clarifies Paul's understanding of the future resurrection or the future eternal life and the true meaning of death. The revelation of Christ gives Paul a perception of the meaning of death. ${ }^{22}$

The Jewish expectation of the future was that God would pour out His Spirit upon His people in a new covenant (Isa. 32:15; 44:3; Ezek. 39:29) and that He would reveal his glory power (Hab. 2:14). ${ }^{23}$ Turner emphasizes that the universal presence of the Spirit of God among His people would result in the deep existential renewal of Israel as illustrated in the mass resurrection from the dead bones in the wilderness (Ezek. 37). ${ }^{24}$ In other words, the Spirit in Old Testament and the Jewish expectation was to perform a prophetic

discussions of "apocalyptic" fail to point out that the word is used to describe two different historical phenomena: a genre of literature, and the particular kind of eschatology embodied in this literature."

${ }^{18}$ Andrew T. Lincoln, Paradise Now and Not Yet: Studies in the role of the heavenly dimension in Paul's thought with special reference to his eschatology (Cambridge, UK: Cambridge University Press, 1981), 169.

${ }^{19}$ Joseph Plevnik, Paul and the Parousia: An Exegetical and Theological Investigation (Peabody, MA: Hendrickson Publishers, 1997), 312-313.

${ }^{20}$ Quoted by Joseph Plevnik, Paul and the Parousia, 13.

${ }^{21}$ Martinus C. de Boer, The Defeat of the Death: Apocalyptic Eschatology in 1 Corinthian 15 and Romans 5 (Sheffield: JSOT Press, no date), 40.

${ }^{22}$ Ibid., 42. Cf. Lincoln, Paradise Now and Not Yet, 172. "1 Enoch 91: 16 in prophesying about the age to come mentions only the new heaven and not a new earth and 1 Enoch 104: 2-6 dwells on the heavenly aspects of the salvation of the righteous (cf. also 2 Bar. 51:8; Assump. Mos. 10: 9ff)."

${ }^{23}$ Turner, Spiritual Gifts in the New Testament Church and Today, 4.

${ }^{24}$ Ibid., 5. Cf. Lincoln, Paradise Now and Not Yet, 193. "Spirit enables the life of heaven to be experienced on earth that the Church itself through its exalted Lord is linked to the heavenly dimension and those experiences such as baptism, worship and visions play an important role in the anticipation of this life of the age to come. This stress on believers' association with heaven through union with Christ does not close the earth or this world to believers but opens them." 
function, to help and enable the people of God, resulting in purification, renewal, righteousness, life, and the salvation of the people of God. ${ }^{25}$

The Spirit as the Spirit of Prophecy in Judaism

Max Turner says that the Spirit in Jewish perspective came to be called the Spirit of prophecy. ${ }^{26}$ Furthermore, Turner emphasizes that it is misleading to believe that the concept of Spirit of prophecy that come from outside of the Jewish tradition. For Turner, the pouring out the Spirit of prophecy in Jewish tradition is the agent of communication between God and His people in different type of gifts. ${ }^{27}$

First it is a prototypical gift. This gift is commonly seen in Jewish writings as the charismatic revelation and guidance of God. ${ }^{28}$ In the Old Testament and Judaism, the gift of revelation is regularly attributed to the Spirit of prophecy because the charismatic revelation provides the basis for the utterance. ${ }^{29}$ The spirit of prophetic is related to charismatic wisdom. In other words, this Spirit leads the mind of the people of God making understanding possible. ${ }^{30}$

Charismatic wisdom is the charismatic revelation in Jewish beliefs. The significant example is provided by Sirach 39:4. ${ }^{31}$ Clearly, the charismatic wisdom is the enthusiasm understanding of the word of God. Therefore, the revelation of the Spirit of God to His people leads them to speak word of wisdom and truth. In other words, the Spirit of prophecy inspired prophetic speech. ${ }^{32}$

Second is the alleged withdrawal of the Spirit of prophecy and the hope for the universal return of the Spirit. In Judaism expectation, that the Spirit of prophecy would be poured out upon the Israelites and restore them at the end. ${ }^{33}$ Therefore, Turner

${ }^{25}$ Archie Hui, "The Spirit of Prophecy and Pauline Pneumatology,” Tyndale Bulletin, 50 no 11999, Publication Type: Article, 99.

26 Turner, Spiritual Gifts in the New Testament Church and Today, 5. The term "Spirit of Prophecy" only became regular in the Targums, from the first century BC to the medieval Aramaic, which was used before the Christian writings Jubilee 31:21 and Philo.

${ }^{27}$ Ibid., 6.

${ }^{28}$ Ibid., 6.

${ }^{29}$ Ibid., 7. See also Sirach 48:24; Enoch 91:1; cf. 4 Ezra14:22.

${ }^{30}$ Ibid., 9.

${ }^{31}$ Ibid., 9. In the midst of worship the wise man who devotes himself to a study the Law the sage expresses his hope: "If the great Lord is willing he [that is, the man devotes himself to the Law] will be filled with the Spirit of understanding; he will pour forth words of wisdom and give thanks to the Lord in prayer."

${ }^{32}$ Ibid., 10.

${ }^{33}$ Ibid., 13. See numbers Rabbah 15:25. "The Number Rabbah is one of a series of homiletic commentaries (midrashim) on biblical book. See also James D. G. Dunn, Jesus and the Spirit: A Study of the Religious and Charismatic Experience of Jesus and the First Christians as Reflected in the New Testament 
emphasizes that Philo and ben Sirach extended the Spirit of prophesy to a wider sector, while the Qumran community appear to have considered all members to share the measure of the eschatological promised of the Spirit. ${ }^{34}$

Third, the Spirit of prophesy is the source of acts of power and is the inspiration for ethical renewal. ${ }^{35}$ The Spirit of prophecy in Judaism expectation provides transforming revelation and ethically renewing wisdom. ${ }^{36}$ Fourth is the Spirit on the Messiah. This Spirit in Jewish expectation enables the Spirit of prophecy or the Spirit of power as the dynamic righteousness that liberating the people of God from the oppositions. ${ }^{37}$

Wright emphasizes that the expectation of the Jews people is the promise land in which the land will be fruitful. This metaphor turns out to be an advance for the renewal of the whole world and rebuilding the temple. And the temple is already a cosmic image in which God will dwell among His people forever and defeat every enemy form including death through the resurrection. ${ }^{38}$ Furthermore, Wright explains that Paul sees this expectation already fulfilled in Jesus as the Messiah through the implementation of the Spirit. 39

\section{Holy Spirit as The Fulfillment of Old Testament Prophecy}

C. Marvin Pate says that the presentation of the Spirit in Old Testament is unclear. The Spirit in Old Testament brought God's people to an eschatological longing for a new day. The Spirit of God was not available to all the people of God but only to select individuals (Ex. 31:3 "the Spirit upon the tabernacle's builders"; Judg. 3:10; 6:34, etc. "the

(Gran Rapids, MI: William B. Eerdmans Publishing Company, 1975), 170. Prophecy and prophets foretold by Joel (2:28-32) was the widespread experience of the gift of prophecy; in the new age of the Spirit the ancient hope of Moses would be fulfilled - 'Would that all the Lord's people were prophets, that the Lord would put his spirit upon them!' (Num. 11:2 9). Luke and/or his source certainly regards Pentecost as that fulfillment, and gives it special emphasis by repeating the 'and they shall prophesy' at the end of v. 18. His belief that all converts were given the gift of prophecy seems to be reflected in $2.17 \mathrm{f}, 38 ; 4: 31 ; 10: 46 ; 19: 6$. Here too we probably see a reflection of the eschatological enthusiasm of the first community and the early mission - their consciousness of Spirit was in large part an awareness inspiration, of direct contact with God, and the fullness of that inspiration together with its widespread distribution evident in the communal gatherings, all confirmed the first Christians' conviction that they were in the end-time and were experiencing the outpouring of the prophetic Spirit."

${ }^{34}$ Ibid., 10.

${ }^{35}$ Ibid., 10.

${ }^{36}$ Ibid., 15.

${ }^{37}$ Ibid., 17.

${ }^{38}$ N. T. Wright, Pauline Perspective: Essay on Paul 1978-2013 (Minneapolis: Fortress Press, 2013), 418.

\footnotetext{
${ }^{39}$ Ibid., 418.
} 
Spirit upon the Judges"; 2 Kings 2:9 "the Spirit upon the prophets" people like Joshua and Daniel in Nah. 27:18). ${ }^{40}$

Furthermore, Marvin emphasizes that in the New Testament the Spirit comes to be seen as a person and not just one of the attributes of God. The Spirit as the Person of God can be experienced by all the people of God and not only select individuals (Acts 2:16). ${ }^{41}$ Paul's understanding of the indwelling of the presence of the Holy Spirit, especially in the eschatological context, results the Holy Spirit taking up the residence in every member of the body of Christ and transforms it into the new temple of the Lord. ${ }^{42}$

The eschatological significance of the promise of the Spirit in the Old Testament is the indwelling of God among His people. ${ }^{43}$ The Israelites are never identified as the temple of God. But Paul describes the Church as the body of Christ. Paul uses this metaphor to describe the indwelling of the Spirit among His people and the Church as the Body of Christ which refers to the New Temple of God. ${ }^{44}$

The Church is the temple of God, the temple of the end times which has now arrived. Paul consistently uses the term Christian or church to describe the temple of God, the actual sanctuary of God. Paul emphasizes that the church or Christians as the body of Christ has become the dwelling place of God, an extension of Christ himself as the new eschatological temple. ${ }^{45}$

The union of the church with Christ is what makes possible this understanding of the temple of God. Plevnik says, "union with Christ is constant in Pauline eschatology."46 As the fulfillment of the Old Testament regarding the indwelling of God among His people, union with Christ shifts the moment of the fulfillment from the future to the present. ${ }^{47}$ Furthermore, Plevnik emphasizes that this union could be understood as the spiritual union with Christ in present life that makes the end time Parousia and resurrection redundant. 48

${ }^{40}$ C. Marvin Pate, The End of the Age has Come: The Theology of Paul (Grand Rapids, MI: Zondervan Publishing, 1995), 150.

${ }^{41}$ Ibid., 151. See Matt. 28:19; Eph. 1:1-14; 1 Peter 1:2

42 Ibid.

${ }^{43}$ Ibid. see Lev. 26:12; Ps. 114:2; Ezek. 37:37.

${ }^{44}$ Ibid. see 1 Cor. 3:16, 6:19; 2 Cor. 6:16; Eph. 2:21.

${ }^{45}$ Ibid., 152. Cf. Mark 14:58; John 2:19-21; 2 Cor. 5:1-5.

${ }^{46}$ Plevnik, Paul and the Parousia, 272.

${ }^{47}$ Ibid.

${ }^{48}$ Ibid. 
Because Christ is the central point in Pauline theology, ${ }^{49}$ union with Christ is an critical element for Christians. Paul compares the new relationship between the believers with the relationship of the church with God. The believer's relationship with God through Christ is the experiential appropriation that changes the life of the believer. The presence of the Holy Spirit is the crucial aspect of this relationship and the conversion of the people of God. 50

Union with God through Christ in the early Christian experience was understood as experience of the Spirit. Spirit Baptism is an experienced and living reality for the Christian life from the beginning to the end. ${ }^{51}$ Spirit in Hebrew is ruach, the breath of life or life from God.52 Following the teaching of the Old Testament, Paul emphasizes the character of the Spirit or pneuma (Greek) as the Spirit of life or the life giver. ${ }^{53}$ Ladd states that to be a Christian means receive life through the Holy Spirit and have life in the Spirit. Paul associates the believers' life in the Spirit with the eschatological existence of the new age. ${ }^{54}$

In the Old Testament, the Spirit of God had a prophetic and creative role. Isaiah and Ezekiel picture the activity of the Spirit as the creator and maintainer of the present nature, as the agent of the God's word in the present age, and the source of the transition from this age to judgment in the age to come. Therefore, Old Testament prophecy foreshadows the present work of the Spirit as an anticipation or type of his future eschatological role.55 The Holy Spirit in the Old Testament also gives a final warning that

\footnotetext{
${ }^{49}$ Lucien Cerfeux, The Christian in the Theology of St. Paul (New York: Herder and Herder, 1967),
} 312.

${ }^{50}$ Fee, God's Empowering Presence, 854.

${ }^{51}$ James D. G. Dunn, The Theology of Paul the Apostle (Grand Rapids, MI: William B. Eerdmans Publishing Company, 2003), 426-427.

${ }^{52}$ Ibid., 428. Cf. Albert L. A. Hogeterp, Expectation of the End: A Comparative Tradition-Historical Study of Eschatological, Apocalyptic and Messianic Ideas in the Dead Sea Scrolls and the New Testament (Leiden, Koninklijke Brill NV, 2009), 255. "Classical examples from Hebrew Scriptures often referred to as exegetical starting points for later traditions about life after death are Isaiah 25:8 and 26:19, Ezekiel 37:1-14, and Daniel 12:1-3 and 12:13. The following evocative imagery in prophetic literature34 speaks the language of

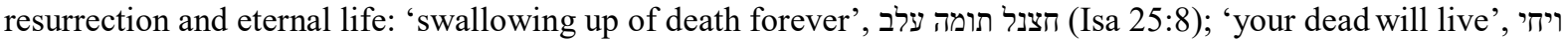

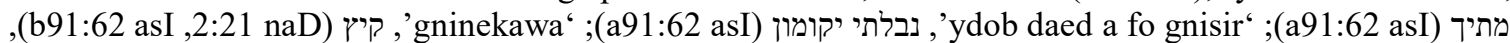
'raising and living before God', וינפל היחנו ונמקי (Hos 6:2), 'resting and standing up for your lot at the end of

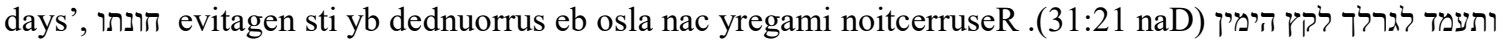
formulation in Isa 26:14, ומקי־לב םיאפר ויחי־לב םיתמ, within a setting of denouncement of wicked people who do not learn righteousness (Isa 26:7-15). Ezekiel 37:1-14 comprises a prophetic vision that bones come together, are covered and come to life out of the graves."

${ }^{53}$ Ibid., 429.

${ }^{54}$ Ladd, A Theology of the New Testament, 526.

${ }^{55}$ E. Earle Ellis, Pauline Theology: Ministry and Society (Grand Rapids, MI: William B. Eermans Publishing Company, 1989), 27. Cf. Isa. 42:1 - 49:6; 61:1f; Ezek. 37:14. 
all God's people will be saved and His enemies judged in the final redemption and regeneration of the natural world. 56

The source of the revelation of the Holy Spirit in Paul's theology was the Old Testament. Paul emphasizes that the Scriptures are holy prophecy (Rom. 1:2; 4:3, cf. 3:13). 57 The Scripture for Paul is "spirit-breathed" (2 Tim. 3:16). The Old Testament is also Paul's source of understanding the Spirit as our source of illumination of the Holy Spirit. The Holy Spirit leads men to understand Old Testament prophecy that the covenant that God gave to His people is now already fulfilled or revealed in Christ. ${ }^{58}$ Therefore, "The Old Testament must be read in the light of fulfillment in Christ with the illumination of the Holy Spirit."59

Gererhardus Vos says that in the Old Testament there is a relationship between Spirit and eschatology. ${ }^{60}$ This connection could be seen first in the idea that through supernatural manifestations the Spirit prophetically declares the coming of the future world (see Joel 3:1ff).61

Second, the Spirit becomes provides supernatural power for the Messiah. This does not imply that the Spirit is for the Messiah but that through the Messiah the Spirit comes and dwells among and in His people. ${ }^{62}$ God dwelling among His people is the important expectation of the People of God in the Old Testament through the coming of the Messiah (Isa. 11:2). Von emphasizes that the Messiah receives the Spirit as a permanent possession. 63

\footnotetext{
${ }^{56}$ Ibid., 27.

${ }^{57}$ Ladd, A Theology of the New Testament, 432.

${ }^{58}$ Ibid., 433.

${ }^{59}$ Ibid., 434.

${ }^{60}$ Geerhardus Vos, The Pauline Eschatology (Grand Rapids, MI: William B. Eerdmans, 1972), 160.

61 Ibid.

${ }^{62}$ Ibid., 161. Further reading Moyer V. Hubbard, New Creation in Paul's Letters and Thought
} (Cambridge, UK: The Press Syndicate of the University of Cambridge, 2004), 115. "Given the importance of the eschatological Spirit in the Old Testament, it remains something of a mystery why this theme was not developed in any significant way in the literature of intertestamental Judaism, Qumran being a possible exception. The clearest examples are found in Testament of Levi 18.7, 9 and Testament of Judah 24.1-3. The former speaks of a new priest (18.2) who will possess "the Spirit of understanding and sanctification" (18.7; cf. Isa. 11.2), and who will usher in a period in which "the Spirit of holiness" will rest on all the righteous (18.911). Testament of Judah 24 prophesies the rise of "a Star from Jacob . . . the Sun of righteousness" who will "pour out the Spirit" to enable Israel "to walk in his first and final decrees" (24.1-3). This eschatological king is later described as "the Shoot of God . . the rod of righteousness for the nations" (24.6). Weaving together the themes of both of these texts, Psalms of Solomon 17 describes the coming of "the son of David" (v. 1), "a righteous king" (v. 32) who will be "powerful in [the?] Holy Spirit" (v. 37)."

${ }^{63}$ Vos, The Pauline Eschatology. 
Third, the Spirit is the source of the promise of God for the future new life of Israel as the people of God. The pouring out of the Spirit of God on His people points to their eschatological existence(Isa. $32: 15-17 ; 44: 3){ }^{64}$ This prophecy is the initial description of the new condition of the presence and the working of the Holy Spirit upon God's people. ${ }^{65}$

Fourth, pouring out of the Spirit in the Old Testament is a supernatural reality. The supernatural element of the Spirit is from above and does not merely denote the miraculous but also the sovereignty of God over His creations. ${ }^{66}$ Apocalyptic literature describes the Spirit as the Spirit of eternal life that is connected with resurrection. ${ }^{67}$ Therefore, the eschatological framework of Paul's theology is based fully upon the Old Testament teaching of the Holy Spirit. ${ }^{6}$

The Holy Spirit in Old Testament is associated with the eschatological framework that refers to the new life. For the Hebrew readers, there is a relationship between the Spirit and life. ${ }^{69}$ The promise of God regarding the pouring out of His Spirit upon His people could be understood in the term eschatological Spirit.

Like Ezekiel, Paul's emphasized the Spirit's the ability to produce life for the present and the future. ${ }^{70}$ Gordon Fee emphasizes that the experience of the Spirit identified the people of God in present eschatological age. ${ }^{71}$ Vos says that Paul's emphasizes one eschatological function of the Spirit is as the source of resurrection, ${ }^{72}$ the Spirit is the agent of resurrection of the death.

\section{Holy Spirit Baptism as the Eschatological Fulfillment}

The key to the eschatological reality in Paul's writing is the dwelling of the Holy Spirit in and among the church. ${ }^{73}$ Those who are indwelt by the Spirit receive the life of

64 Ibid.

${ }^{65}$ Ibid.

${ }^{66}$ Ibid., 162.

${ }^{67}$ Ibid. See also Orac. Syb. 3:771.

${ }^{68}$ Hubbard, New Creation in Paul's Letters and Thought, 113.

${ }^{69}$ Ibid., 116. See Ezek. 11:19; 18.31; 36: 27; 37:14 ; 36:26

${ }^{70}$ Ibid., 120. See also Romans 8:23-24.

${ }^{71}$ Fee, God's Empowering Presence, 855.

72 Vos, The Pauline Eschatology, 163,

${ }^{73}$ Mark Pretorius, "The theological centre of Pauline theology as it relates to the Holy Spirit," Hervormde Teologiese Studies, 62 no 1 (Mar 2006), 257. 
the coming age now from God. ${ }^{74}$ Dunn emphasizes that the Christian life which Paul attributes to the Spirit is the beginning of the new life and the beginning of salvation. ${ }^{75}$

The central character in Pauline pneumatology is the Spirit who brings life to mankind. The basic experience of the Spirit for Paul is the Spirit as the breath of life. ${ }^{76}$ G. $\mathrm{K}$. Beale notes that in his letter to the Corinthians, Paul instructs them how to live in the end times because the end of the age has come (1 Cor. 10:11). Paul refers to the birth of Christ as the fulfillment of the messianic prophecies (Gal. 4:4)77

The fullness of the time refers to the deliverance of the believers from the bondage of Satan and sin through the death and the resurrection of Christ. The death and the resurrection of Christ is the beginning of the eschatological event or the new creation prophesied by Isaiah (Isa. 43; 65 - 66, cf. 2 Cor. 5:17). ${ }^{78}$ Lucien Cerfaux emphasizes that the eschatological mysticism of Paul in the presence of Christ means that Christians have already been resurrected and have the Spirit in this life. ${ }^{79}$

Ellis emphasizes that function of the Holy Spirit upon the believers is baptism in the Spirit. This function brings a person into the church as a member of the body of Christ (1 Cor. 12:13). The baptism in the Spirit means to belong to Christ and belong to Christ means to have the Spirit. 80 Dunn stresses that experience of the Spirit in the Christian life should be considered the climax of the saving work of the Spirit and as the liberation of the human body. (Rom. 8:21-23). ${ }^{81}$ Therefore, the Spirit Baptism as the work of the Holy Spirit in Paul is best seen in the soteriological metaphors.

Adoption

Paul does not emphasize living under the Law but in the Spirit (Gal. 4:4-6). Paul encouraged Gentile believers to understand that they are the "the sons of God" with full rights through their experience with Holy Spirit. ${ }^{82}$ In Rom. 8:15, Paul also describes the Spirit as "the Spirit of Adoption." James Dunn states, "It is clear enough the indication

\footnotetext{
74 Ibid.

75 Dunn, The Theology of Paul the Apostle, 434,

${ }^{76}$ Ibid.

${ }^{77}$ G. K. Beale, A New Testament Biblical Theology: the Unfolding of the Old Testament in the New (Grand Rapids, MI: Bake Academic, 2011), 140.

${ }^{78}$ Ibid., 141.

${ }^{79}$ Cerfaux, The Christian in the Theology of St. Paul, 354.

${ }^{80}$ Ellis, Pauline Theology, 30-31.

${ }^{81}$ Dunn, The Theology of Paul the Apostle, 435.

${ }^{82}$ Fee, God's Empowering Presence, 856.
} 
that the sense of sonship, both experience in and expressed through the 'Abba' prayer, was common in most churches of the diaspora."83

Paul encourages his fellow Christians with the personal assurance that they were indeed the children of God via the cry of "Abba, Father!” (Rom. 8:16). Cerfaux says that the Christians who have a personal union with Christ, the only Son of God, also will become the sons of God. The Spirit will teach believers to express their feelings in this new relationship with the Father. ${ }^{84}$

Furthermore, Cerfaux emphasizes that the context of 1 Cor. 1:9 regarding the "fellowship" with Christ, the Son of God, should be considered as having an eschatological attribution. ${ }^{85}$ The concept of sonship is bound up with the inheritance that the believers already possess. This privileged condition is given by the Holy Spirit. ${ }^{6}$ The Holy Spirit also helps every believer to appreciate their true status as the sons of God (Gal. 3:26ff). ${ }^{87}$ There is no doubt that Christians are sons of God, "The Father sent His Spirit into our hearts, that Holy Spirit who is the Spirit of His Son, and who speaks in us as the Son of God speaks; we pray as he prayed."88

\section{Washing/Rebirth/Life-Giving}

The metaphor of washing is another of the works of the Spirit (1 Cor. 6:11) as it relates to baptism. The context of this passage is to emphasize the metaphor of "washing away of $\sin ^{\prime}$ (v. 9-10). The work of the Holy Spirit in this metaphor is "cleansing." 89 Fee stresses that the metaphor "rebirth" and "renewal" by the Holy Spirit in Paul are close to Paul's understanding of "regeneration". The beginning of life in Christ is given by the Spirit himself. 90

Conversion in Paul understanding is the experience of the "life giving Spirit." 91 In the Old Testament, Yahweh is the "life giving God". For Paul, every believer receives the

\footnotetext{
${ }^{83}$ Dunn, The Theology of Paul the Apostle, 437.

${ }^{84}$ Cerfaux, The Christian in the Theology of St. Paul, 263.

${ }^{85}$ Ibid., 323.

${ }^{86}$ Ibid., 324.

${ }^{87}$ Ibid., 325.

${ }^{88}$ Ibid., 326.

${ }^{89}$ Fee, God's Empowering Presence, 857.

${ }^{90}$ Ibid., 858.

${ }^{91}$ Ibid., 858.
} 
"Spirit of life" (Rom. 8:2,6) who gives life to those who believe in Christ. This conversion from Paul's perspective includes walking in the "newness of life."92

Turner says that "new creation" in Paul's language and "regeneration of God's people" in Ezekiel 36-37 are not only metaphors for the individual's inward renewal of heart and spirit by the dwelling of the Spirit of God, but also includes the theme resurrection and new creation of the cosmic renewal. ${ }^{93}$ New creation by the Spirit in Paul's theology is part of the new creation in the age to come which will be consummated when Christ comes for the second time.

In Romans 7:6, the "Oldness of letter" and "newness of Spirit" in Paul's understanding of the Spirit is significant in the redemptive program of God. ${ }^{94}$ The "Spirit," "newness," and "life" in Paul are equally as important as is the role of Christ in creating a new life (Gal. 2:19-20). ${ }^{95}$ Pretorius says,

"Christologically, the function of the Spirit is to reveal Christ to man, bind the believer to Christ, and to impart to the believer the risen Christ's life of resurrection and exaltation." 96

The work of Christ in the redeemed future has been brought into the present through the work of the Holy Spirit. ${ }^{97}$ Concerning the present nature of future salvation, Archie Hui says, "The Spirit is the agent of washing or sanctification or justification (Rom. 15:16; 1 Cor. 6:11; 2 Cor. 3:8-9; 2 Thes. 2:13; Tit. 3:5), the giver of eschatological life, whether present" (Rom. 7:6; 8:2-10; 2 Cor. 3:6; Gal. 4:29; 5:25; Tit. 3:5) or future (Rom. 8:13; 1 Cor. 15:44-46; Gal. 6:8). ${ }^{98}$

\section{Sanctification}

The experience of the salvation includes the "sanctification of the Spirit and believe in the truth" (2 The. 2:13). Paul emphasizes that when the Gentiles received the Spirit it was the ultimate act of God of creating for himself a "sanctified offering" composed of both Jews and Gentiles for the holy purpose of God. ${ }^{99}$

\footnotetext{
92 Ibid., 858.

93 Turner, The Holy Spirit and Spiritual Gifts, 119-120.

${ }^{94}$ Hubbard, New Creation in Paul's Letters and Thought, 121.

95 Ibid., 122.

${ }^{96}$ Pretorius, "The theological centre of Pauline theology as it relates to the Holy Spirit," 259.

${ }^{97}$ Ibid.

${ }^{98}$ Hui, The Spirit of Prophecy and Pauline Pneumatology, 113.

${ }^{99}$ Fee, God's Empowering Presence, 859.
} 
Fee says that the use of sanctification imagery refers to 1 Cor. 6:11 where Paul emphasizes that "conversion includes the sanctifying work of the Spirit that disallows the kind of behavior in which they formerly engaged." 100 The sanctifying work of the Spirit is connected with the justification of God. God justifies or sanctifies His people through the revelation of righteousness as a demonstration of the power of God unto salvation (Rom. 1:17). Therefore, union with Christ through the work of the Holy Spirit is the hope of righteousness. ${ }^{101}$

The entire work of Paul centers on the death and resurrection of Christ, and his gospel is justification by faith. ${ }^{102}$ The only possible way to be justified before God is through the sanctifying work of the Holy Spirit and belief in the revelation of the righteousness of God that provides through the death and the resurrection of Christ. ${ }^{103}$

Carfaux emphasizes that "The moment of our call to the Christian life, as well as in continuous passage of this life between justification and glorification."104 God redeems his people through the blood of Christ; He rose from the dead and reestablished a new creation (Eph. 1:3-14). ${ }^{105}$ Verses 13-14 show that the Holy Spirit is the guarantee of the eschatological promise in Paul's theology.

\section{Down Payment}

The Spirit in Paul's eschatology is also an evidence and guarantee of a future event. Paul emphasizes the role of the Spirit as the present evidence guarantor of the Future. Three different times, Paul calls the Spirit the "down payment" or the guarantee of the present evidence of the future (see 2 Cor. 1:21-22; 5:5; Eph. 1:14). ${ }^{106}$

Paul uses the term "down payment" to emphasize the role of the Spirit as the guarantee for the future event and at the same time he tells us that the future event has

100 Ibid.

${ }^{101}$ Herman Ridderbos, Paul: An Outline of His Theology, translated by John De Witt (Grand Rapids, MI: William B. Eerdmans Publishing Company, 1975), 166.

102 Ibid.

${ }^{103}$ Ibid. See also Romans 3:21-31 "But now the righteousness of God has been manifested apart from the law, although the Law and the Prophets bear witness to it the righteousness of God through faith in Jesus Christ for all who believe. For there is no distinction: for all have sinned and fall short of the glory of God, and are justified by his grace as a gift, through the redemption that is in Christ Jesus, whom God put forward as a propitiation by his blood, to be received by faith. This was to show God's righteousness, because in his divine forbearance he had passed over former sins. It was to show his righteousness at the present time, so that he might be just and the justifier of the one who has faith in Jesus."

${ }^{104}$ Cerfaux, The Christian in the Theology of St. Paul, 328.

105 Ibid.

${ }^{106}$ Fee, Paul, the Spirit, and the People of God (Peabody, MA: Hendrickson Publishers), 54. 
begun to be experienced in the present. Fee says that the Spirit of promise comes directly out of the future expectation of Jewish heritage of Paul and this promise already fulfilled as the guarantee of the future inheritance. ${ }^{107}$

Furthermore, Fee emphasizes that the Spirit that God pours out upon His people serves as the down payment of God in the present time, which is the certain evidence that the future has come into the present. ${ }^{108}$ In regards to Acts 2:33 he states, "The Holy Spirit is the sign of the presence of the future event as well as the proof that Jesus currently reigns in heaven in power and glory."109

Therefore, Paul reminds all believers that although they are the citizens of the age to come, they are still bound to their appointed roles in this present age (Eph. 5:28-29).110 Paul's command to every believer to be filled with Holy Spirit points to the arrival of the age to come.111 In other words, the Holy Spirit in the believers serves as the down payment for the age to come.

First Fruits

The Holy Spirit is the believers' guarantee of the future blessing. Paul emphasizes that the resurrection of Christ is the "first fruit" or the guarantee of the future resurrection of the believers (Rom. 8:23 and 1 Cor. 15:20-23). Fee explains that the Spirit plays the leading role Romans 8:12-30. Through the Spirit, believers have already received adoption as the children of God, and through the same Spirit also believers await the final resurrection. ${ }^{112}$

The existence of the future in the present takes place through the adoption of the believers as the children of God. The "not yet" relates to the final consummation by resurrection from the death. The Paul's eschatological framework stresses the present role of the Spirit as both evidence and guarantee that the future is already and not yet.113

Christ is the first fruit of the resurrection of the dead and the Holy Spirit is the guarantee that believers will be resurrected in the future. James Dunn explains the correlation between the Spirit and hope for the resurrection of the dead and classifies

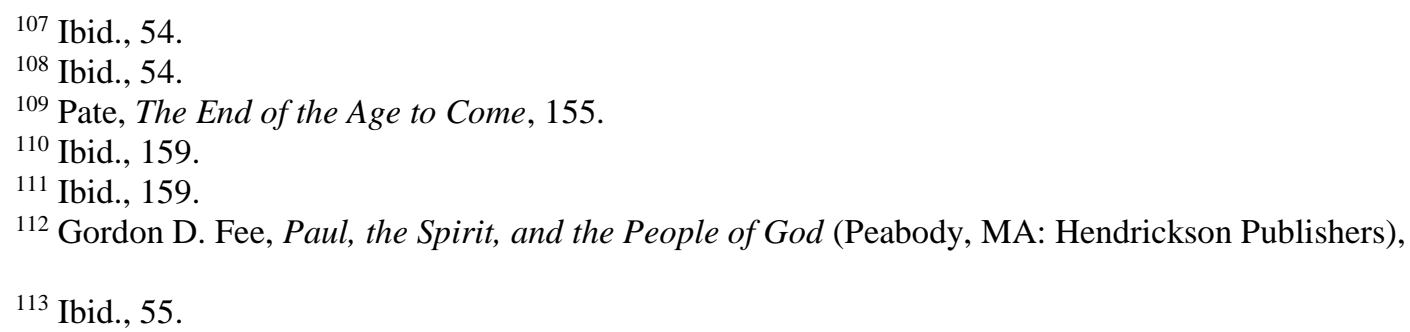


this hope as one of the primary blessings of the Spirit.114 Furthermore, Dunn says in Romans 8 that Paul emphasizes the correlation between receiving the Spirit and believing in Christ to be important for the early Christians' understanding of their experience. ${ }^{115}$

Seal

The metaphor "seal" in Paul's writing occurs three times that directly refer to the Holy Spirit (2 Cor. 1:21-22; Eph. 1:13; 4:30). Literally, a seal is "a stamp impression in wax or clay, signaling ownership and authenticity, and carrying with it the protection of the owner."116 Paul uses the term "seal" in 2 Corinthians 1:21-22 and Ephesians 1:13 to mark believers as God's possession. This seal is the guarantee of the future in which Paul expressly stated "With whom you were sealed for the day of redemption" (Ephesians $4: 30) .117$

The initial coming of the Spirit, called "down payment," "first fruit," or "seal," is the connection between the first coming upon the individual person of Christ. The Spirit who was active in the earthly ministry of Jesus was also active in the resurrection of Jesus from the dead. Through the Spirit in believers, they participate in the resurrection of Jesus in the present and also receive the final resurrection as the final consummation. ${ }^{118}$

\section{Realized Eschatology in Pauline Theology}

In Philippians 3:20, Paul expresses a "realized eschatological." This means that every believer can enjoy the future expectation in the present existence. The tension between the present and the future is maintained as spatial and temporal categories are interwoven. ${ }^{119}$ Paul emphasizes the "already" of the future existence in his theology. The future has been brought to the present existence. In other words, Paul's theology concerning the eschatological framework is realized eschatology.

${ }^{114}$ Dunn, The Theology of Paul the Apostle, 438.

115 Ibid., 439.

${ }^{116}$ Fee, Fee, Paul, the Spirit, and the People of God, 55.

${ }^{117}$ Ibid. See also Cerfaux, The Christian in the Theology of St. Paul, 277. "In 2 Corinthians 1:21-22, seal and pledge are three ways of expressing the efficiency of the Holy Spirit on the Christian. The metaphor of the seal, like that of pledge, takes its place quite naturally in the context of legal construction in which the idea of the promise is set. This context is clearly attested by Eph. 1:13 ff., in which the two images of seal and pledge are again conjoined: "You also, who have believed in him, were sealed with the promised Holy Spirit, which is the guarantee of our inheritance." The seal is the covenant entered into by God to give his promise a more solemn witness."

${ }^{118}$ Ellis, Pauline Theology, 33.

${ }^{119}$ Lincoln, Paradise Now and Not Yet, 101. 
The evidence of the presence of the future in Paul's eschatology is the earthly ministry of Jesus and the fulfillment of the promise of God regarding the Holy Spirit that God will pour out His spirit upon His people on the last day.

\section{Through Christ}

The death and the resurrection of Christ are eschatological events in Paul's theological understanding. Therefore, the blessings of the age to come are not only exclusively a future event but also become available in present experience. ${ }^{120}$ Because the death of Christ is an eschatological event, when Christ Jesus justifies a person in the present, he or she is also justified in the age to come and before the eschatological judgment to come.

The death of Christ transfers the believers from the ruler of the darkness to the Kingdom of Christ (Col. 1:13). On the cross, Jesus defeated the power of evil (Col. 2:14). In the resurrection of Christ from the death, Paul emphasizes that the glory of the resurrection in the age to come has already been shown in this age through the resurrection of Christ (2 Tim. 1:10; 2 Cor. 4:6). ${ }^{121}$

Through the Holy Spirit Baptism

In Paul's thinking, the Old Testament promise of the coming Messiah has clearly been fulfilled in Christ. The Jews hoped for the return of YHWH to His people as seen in the imagery of the temple in which God dwells among His people through His divine Spirit. ${ }^{122}$ For Paul, the temple applies equally to the Messiah and His Spirit that filled the people of God (see Romans 8:9-11). The "indwelling" of the Spirit among the people of God is a strong indication of the implicit "temple" theme in Paul's thought. ${ }^{123}$

Wright emphasizes that Paul sees the expectation of Jewish people as realized in the present existence, in a radical new way, reconceived around the Messiah and the

\footnotetext{
${ }^{120}$ Ladd, A Theology of the New Testament, 596.

${ }^{121}$ Ibid. "The eschatology events that the believers experience in the present existence are they live in the life of the new age. The very phrase describing the status of the believers, 'in Christ,' is an eschatological term. To be 'in Christ' means to be in the new age and to experience its life and powers. 'If anyone in Christ, he is a new creation; the old has passed away, behold, the new has come' (2 Cor. 5:17). Believers already experienced death and resurrection (Rom. 6:3-4). They have even been raised with Christ and exalted to heaven (Eph. 2:6), sharing the resurrection and the ascension life of their Lord."

${ }^{122}$ Wright, Paul and the Faithfulness of God, 1074.

${ }^{123}$ Ibid, 1074.
} 
Spirit. The realization of the age to come into the present existence is clearly important but is not yet the final consummation. Paul expressed a messianic and pneumatological hope in reworking of the Jewish hope. ${ }^{124}$

Jesus fulfilled the promise of God in the Old Testament that the coming Messiah would pour out of the Spirit upon the people of God. Beale explains that the resurrection of Christ which Paul experienced on the road to Damascus revealed that Christ was the eschatological king who fulfilled the Old Testament promise.125 Beale adds, "the resurrection of Jesus establishes the inaugurated end-time new-creational kingdom."126

With the promise that God will pour out His Spirit upon His people (Ezek. 36:2627), Paul emphasizes that "the first fruit of the Spirit" (Romans 9:18-23) is the beginning of the new resurrection life created in the Christian through the indwelling of the Spirit. ${ }^{127}$

\section{Future Eschatology in Pauline Theology}

Ladd says that the main center of the eschatology of Paul is the consummation of the saving purpose of God. This saving action of God is not yet finished. ${ }^{128}$ Paul believed that the first coming of Jesus the Messiah and the indwelling of the Spirit among the believers means in one sense that the new day had already dawn. This is the day in which the work of God would be consummated in the future when God will defeat all rulers and powers (1 Cor. 15:20-28).129

The futuristic element in Pauline eschatological theology can be seen in the resurrection of the dead, the Day of Judgment, and eternal life. These events in Paul point to the redemptive significance of the parousia of Christ. ${ }^{130}$ Ladd says that the coming of Christ (parousia) is a definitive event for all people either for their salvation or judgment. ${ }^{131}$

${ }^{124}$ Ibid., 1078 .

${ }^{125}$ Beale, A New Testament Biblical Theology, 247.

${ }^{126}$ Ibid., 249. See also 1 Cor. 15:21-26: 'For since by a man came death, by a man also came the resurrection of the dead. For as in Adam all die, so also in Christ all will be made alive. But each in his own order: Christ the first fruits, after that those who are Christ's at His coming, then the end, when He delivers up the kingdom to the God and Father, when He has abolished all rule and all authority and power. For He must reign until He has put all His enemies under His feet. The last enemy that will be abolished is death."

${ }^{127}$ Ibid., 256.

${ }^{128}$ Ladd, A Theology of the New Testament, 597.

${ }^{129}$ Wright, Paul and the Faithfulness of God, 1080.

${ }^{130}$ Redderbos, Paul, 537.

${ }^{131}$ Ladd, A Theology of the New Testament, 602. 
Resurrection of the Death

Paul's eschatological emphasis is evident when he teaches that the resurrection of Christ is a present condition that the believers experience now and also a future hope for the resurrection of the death (see 2 Cor. 15:19). The future expectation of believers is to go where Jesus has already gone. ${ }^{132}$ Johnson says, "Paul's language of $\pi v \varepsilon v ́ \mu \alpha$ refers to "the Holy Spirit" $(6: 19 ; 12: 3)$ or the 'Spirit from God' $(2: 11-12 ; 2: 14 ; 3: 16 ; 6: 11 ; 7: 40$; 12:3) . . . At least three aspects of such usage require attention in relation to the ontological implications of resurrection."133

The Christological approach to the resurrection of the dead in Paul should be understood in relation to the resurrection and the Holy Spirit. Ridderbos explains that it was the Holy Spirit who resurrected Christ. Therefore, the resurrection of Christ should be related to the work of Spirit. ${ }^{134}$ Paul emphasizes that the resurrection of Christ is the basis of all belief in a resurrection of the dead (1 Cor. 15:11-34). ${ }^{135}$

The consummation of salvation is at the resurrection from death (Eph. 1:14) which takes places in the Parousia or in the second coming of Christ (1 Thess. 4:14). Dunn emphasizes that Roman 8:2-9 makes clear the deliverance of the body from the sin and death will only happen at the resurrection of the body. In other words, the complete salvation that God will give by "giving life to their mortal bodies" (Romans 8:11). ${ }^{136}$

Fee argues that the Holy Spirit is not the agent of the resurrection of the Christ. For him, there is no text in Paul in fact attributes the resurrection of Christ as the work of the Holy Spirit. ${ }^{137}$ Furthermore, Fee explains that the statement of Romans 8:11,

"If the Spirit dwells in us," that is, "the Spirit of the very God" who raised Christ, says something significant about our future in which the Spirit as our guarantee for the mortal bodies. ${ }^{138}$

Fee's view only suggests that the Holy Spirit plays a role for believers as the guarantee of the resurrection of the body of the believers in the future. Concerning the

\footnotetext{
${ }^{132}$ Luke Timothy Johnson, "Life-Giving Spirit: The Ontological Implications of Resurrection," StoneCampbell Journal, 15 no 1 (September 2012), 79.

133 Ibid., 85.

${ }^{134}$ Redderbos, Paul, 538.

135 Ibid., 540.

${ }^{136}$ Dunn, The Theology of Paul the Apostle, 480.

${ }^{137}$ Fee, God's Empowering Presence, 808.

138 Ibid., 809.
} 
resurrection of Christ, the Spirit of the very God is the one who raised Christ from the death. Is the Holy Spirit different from the Spirit of the very God?

It is better to say that the Holy Spirit is the Spirit of the very God. Therefore, the Holy Spirit could be understood as the agent of the resurrection of Christ from the death and also the agent of the resurrection of the body in future event. Resurrection could be seen as the consummation of the salvation and the judgment for the people according their works. 139 The Holy Spirit guarantees believers that they will receive salvation in which God sanctifying them as mentioned above.

Final Judgment

Judgment is an eschatological fact even for believers. But the decision has already been rendered for the believers through the death of Christ (Romans 3:21-26). The believers' present justification assures them that they will be saved from the wrath of the Day of Judgment (Rom. 3:21-26). ${ }^{140}$ In 1 Corinthians 3:12-15, Paul emphasizes that believers will be fully answerable for the quality of their present lives in the body, but that their eternal salvation has been assured by their justification in Christ. ${ }^{141}$

The expectation of future judgment in Paul is related to the parousia of Christ and the resurrection of the dead. ${ }^{142}$ This future judgment has the goal of salvation and not only destruction (1 Cor. 5:4ff). ${ }^{143}$ Believers will be judged in the future but with a different judgment than that for unbelievers.

Believers will be secured by Christ (1 Thess. 1:10; cf. Eph. 6:9; Col. 3:24, 25). Here, Paul wants the church to understand that being with Christ or against Christ has not only present implications, but also in the great future to come. ${ }^{144}$ Judgment on the believers and on the unbelievers presupposes a resurrection of the body for the unbelievers as well (1 Corinthians 15). ${ }^{145}$

Eternal Life

${ }^{139}$ Ladd, A Theology of the New Testament, 611. See Romans 2:5 "But because of your stubbornness and your unrepentant heart, you are storing up wrath against yourself for the day of God's wrath, when his righteous judgment will be revealed."

${ }^{140}$ Ibid., 612.

141 Ibid.

142 Redderbos, Paul, 551.

143 Ibid., 553.

144 Ibid., 554.

145 Ibid. 
Ridderbos says, "The Parousia of Christ with the accompanying resurrection of the dead and execution of the judgment at the same time forms the transition to the consummation of all things and eternal state." 146 The purpose of the redemption of God at the end of this age is that God will reconcile all things to Himself through Christ (Col. 1:14-20). This reconciliation is not only for the spiritual realm of human being but also nature itself. 147

Death for Paul is the penalty of $\sin$ (Rom. 5:12; 1 Cor. 6:16, 23). In other words, death is the opposite of the eternal life (Rom. 6:23; 7:10; 8:6; 2 Cor. 2:16) and is the present basis for one's future fate (Rom. 1:32; 6:16, 21, 23; 7:5).148 Therefore, the final reconciliation in Paul's theology is the salvation of the all things or universal reconciliation. This means God will restore peace between Him and human being as the blessings of life for human being that come from the enjoyment of the divine presence of the God. 149

Eternal life in this history of salvation is received at the end of the time when Christ comes from heaven to earth to open the final act of the drama of the universe (1 Thess. $4: 16) .{ }^{150}$ Eternal life refers to the new life that the believers will receive in the final resurrection. The new life of the resurrection is for those who believe in Christ and will receive communion with Him in the age to come. ${ }^{151}$ Indeed, this expectation is what Paul desires, that through the Spirit "of wisdom" and "of revelation" Paul would know Him in an eternal union.

\section{Conclusion}

Spirit Baptism in Paul's pneumatology and eschatology cannot be separated. The Holy Spirit plays a significant role of Paul's eschatology. The Holy Spirit is the fulfillment of the promise of God in Old Testament in which God will pour out His Spirit upon His people. This is also known as the Spirit Baptism which means God will dwells among His people.

This promise refers to the new temple that God will fill with His Spirit to fulfill the Old Testament's promise of God. The promise that Spirit of God Himself will come and

\footnotetext{
146 Ibid., 556.

${ }^{147}$ Ladd., A Theology of the New Testament, 612.

${ }^{148}$ Ibid., 614.

149 Ibid.

${ }^{150}$ Lincoln, Paradise Now and Not Yet, 188.

${ }^{151}$ Ridderbos, Paul, 560.
} 
dwell among and with His people has already been fulfilled in the present. Paul emphasizes that the earthly ministry of Jesus points to the current present of the future.

Paul's eschatological framework is a realized and future eschatology. Realized eschatology means that the future is already present through Christ and the indwelling of the Spirit among the Church. The Church is both the individual people of God and also as the symbol of the temple of God. Therefore, the indwelling of Spirit upon the church is a fulfillment of the promise of God in the Old Testament in which God will redeem His people through giving them His Spirit and a new life.

Spirit Baptism in Pauline theology should be understood as the mission of God through the soteriological role of the Spirit upon His people. The Holy Spirit plays an important role in the soteriological work in the history of the universe. The Old Testament emphasizes the soteriological work of the Spirit upon the universe and especially to the people of God.

Because Paul had a Jewish background, his thought about the Spirit Baptism cannot be separated from the idea of the Old Testament and the interpretation of the Judaism tradition regarding the eschatological promise of God in pouring out the Holy Spirit upon the people of God. Therefore, Spirit Baptism in Paul's perspective is inherited from Jews tradition that emphasize the soteriological dimension work of the Holy Spirit.

\section{BIBLIOGRAPHY}

Beale, G. K. A New Testament Biblical Theology: the Unfolding of the Old Testament in the New. Grand Rapids, MI: Bake Academic, 2011.

Bruce, F, F. Paul: Apostle of the Heart Set Free (Grand Rapids, MI: Williams B. Eerdman Publisher, 1997, electronic edition.

de Boer, Martinus C. The Defeat of the Death: Apocalyptic Eschatology in 1 Corinthian 15 and Romans 5. Sheffield: JSOT Press, no date.

Dunn, James D. G. Jesus and the Spirit: A Study of the Religious and Charismatic Experience of Jesus and the First Christians as Reflected in the New Testament. Gran Rapids, MI: William B. Eerdmans Publishing Company, 1975. . The Theology of Paul the Apostle. Grand Rapids, MI: William B. Eerdmans Publishing Company, 2003. 
Ellis, E. Earle. Pauline Theology: Ministry and Society (Grand Rapids, MI: William B. Eerdmans Publishing Company, 1989.

Fee, Gordon D. God's Empowering Presence: the Holy Spirit in the Letters of Paul. Peabody, MA: Hendrickson Publishers, 1994. . Paul, the Spirit, and the People of God. Peabody, MA: Hendrickson

Publishers.

Hogeterp, Albert L. A. Expectation of the End: A Comparative Tradition-Historical Study of Eschatological, Apocalyptic and Messianic Ideas in the Dead Sea Scrolls and the New Testament. Leiden: Koninklijke Brill NV, 2009.

Hubbard, Moyer V. New Creation in Paul's Letters and Thought. Cambridge, UK: The Press Syndicate of the University of Cambridge, 2004.

Hui, Archie. "The Spirit of Prophecy and Pauline Pneumatology," Tyndale Bulletin, 50 no 1 1999, Publication Type: Article, 93-115.

Johnson, Luke Timothy. "Life-Giving Spirit: The Ontological Implications of Resurrection," Stone-Campbell Journal, 15 no 1 (September 2012), 75-89.

Ladd, George Eldon. A Theology of the New Testament, revised edition. Grand Rapids, MI: William B. Eerdmans Publishing Company, 1993. The Present of the Future: The Eschatology of Biblical Realism, revised edition. Grand Rapids, MI: William Eerdmans Publishing Company, 2002.

Lincoln, Andrew T. Paradise Now and Not Yet: Studies in the role of the heavenly dimension in Paul's thought with special reference to his eschatology. Cambridge, UK: Cambridge University Press, 1981.

Manoussakis, John Panteleimon. "The Promise of the New and the Tyranny of the Same," Pneumatology and Eschatology: Not Yet in the Now, edited by Neal Deroo and John P. Manoussakis. Barlington, USA: Ashgate Publishing Company, 2009.

Pate, C. Marvin. The End of the Age has Come: The Theology of Paul. Grand Rapids, MI: Zondervan Publishing, 1995.

Plevnik, Joseph. Paul and the Parousia: An Exegetical and Theological Investigation. Peabody, MA: Hendrickson Publishers, 1997. 
Pretorius, Mark. "The theological centre of Pauline theology as it relates to the Holy Spirit," Hervormde Teologiese Studies, 62 no 1 (Mar 2006), 253-262.

Ridderbos, Herman. Paul: An Outline of His Theology, translated by John De Witt. Grand Rapids, MI: William B. Eerdmans Publishing Company, 1975.

Segal, Allan F. "Paul's Jewish Presuppositions," The Cambridge Companion to St. Paul, edited by James Dunn. Cambridge, UK: Cambridge University Press, 2004.

Turner, Max. Spiritual Gifts in the New Testament Church and Today, revised edition. Peabody, MA: Hendrickson Publishers, 1998.

Vos, Geerhardus. The Pauline Eschatology. Grand Rapids, MI: William B. Eerdmans, 1972.

Wright, N. T. Pauline Perspective: Essay on Paul 1978-2013. Minneapolis: Fortress Press, 2013.

. What Saint Paul Really Said: Was Paul of Tarsus the Real Founder of Christianity? Grand Rapids, MI: William B. Eerdmans Publishing Company, 1997.

About the author

He completed postgraduate theology study at Asia Pacific Theology Seminary, Manila (APTS, www.apts.edu), and now serves as a lecturer at STT Satyabhakti, Malang, Indonesia. 